\title{
Bioclimatic diagnosis for dairy cattle breeding in João Pessoa, Brazil
}

\author{
Patrícia Venâncio da Silva Medeiros • Fabrício Macêdo Furtado •
} Matheus Serrano de Medeiros • José Ronaldo Brandão Júnior

PVS Medeiros (Corresponding author) - FM Furtado - MS

email: paty_venancio17@hotmail.com

\section{Medeiros - JR Brandão Júnior}

Programa de Pós-Graduação em Engenharia Agrícola, Universidade Federal de Campina Grande (UFCG), Bairro Universitário, Campina Grande, PB, 58428-830, Brazil.

Received: January 10, 2019 • Revised: February 09, 2019 • Accepted: February 24, 2019

\begin{abstract}
One of the environmental elements that have a more pronounced effect on animal welfare is the climate, and as a result, negatively impacts productive performance and is considered a regulating or even restrictive element of animal exploitation for economic purposes. The ambient temperature range within which the animal maintains body temperature without the need for activation of thermoregulatory mechanisms is called the thermal comfort zone (TCZ), where the thermal equilibrium occurs naturally. The TCZ varies among the different species of domestic animals, where the minimum and maximum values of this range are influenced by the climate elements. Thus, within the animal bioclimatology, the environmental diagnosis can be highlighted that allows support regarding the information of variation and ideal environmental conditions for animal exploration, as well as, help in management measures that minimize the effect of the thermal challenge and enable the maximization of productivity animal. This research aimed to carry out the environmental diagnosis for dairy cattle in the municipality of João Pessoa, Brazil, based on average, maximum and minimum temperatures, BGHI and relative humidity. According to the results, both dairy cows and calves have thermal discomfort caused by high temperatures. As a way to reduce heat stress, it is necessary for some environmental modifications that aim to mitigate the stressors actions on the animals. According to our analysis, the bioclimatic diagnosis for João Pessoa presents a need for improvement of the facilities to provide the animals with thermal comfort, thus making it possible for these animals to present a higher production yield.
\end{abstract}

Keywords: bovine farming, facilities, thermal comfort

\section{Introduction}

Milk agribusiness is one of the most important segments of Brazilian agriculture. This activity has been undergoing transformations in the last decades due to the new reality in the dairy production sector with animal welfare requirements, increase in milk quality and yield. Despite the low average productivity of herds, which is 1,237 liters/cow/year (FAO 2014), Brazil has been growing exponentially in recent years. This same scenario has been repeated in the state of Paraíba, which, although it has been suffering from severe droughts in recent years, has presented a growth rate of around 6\% per year (IBGE 2015).

Cattle breeding is an activity that is highly dependent on climate factors, whose alterations can affect animal productivity and management, attenuating and prioritizing welfare and thermal comfort (Domingos et al 2013; Rashamol et al 2018). The climate has an effect on animal welfare, directly influencing productivity and production, being considered as a regulating or limiting factor of animal exploitation with an economic purpose (Pereira 2005).

The temperature range within which the animal maintains its body temperature without the need for activation of thermoregulatory mechanisms is called the thermal comfort zone (TCZ). In this range, the thermal equilibrium is achieved naturally. The minimum and maximum values of TCZ are also influenced by other climate factors and are variable among the various domestic species (Medeiros and Vieira 2013).

Animals exposed to solar radiation have in this meteorological variable the main responsible for the increase of body temperature. During the day, almost all the heat absorbed comes from direct or indirect solar radiation, constituting one of the main causes of heat stress in animals. In this way, the provision of shading aims to attenuate the effect of radiation on the animals, in which their degree of importance varies with the microclimate and its efficiency (Baêta e Souza 2010).

According to Carvalho and Moraes (2005), one of the forms of signal transmission by the animal is through ingestive behavior, on the quantity and quality of the available fodder, interfering in the animal distribution and performance in the pasture. The main components of the grazing behavior studied 
are grazing time, rumination, idleness and these, interconnected to water and shade search. The time allocated to each of these activities depends on the pasture characteristics, the environmental conditions, the animal nutritional requirements and the production system adopted (Zanine et al 2007).

Thus, within the animal bioclimatology, the environmental diagnosis can be highlighted that allows support regarding the information of variation and ideal environmental conditions for animal exploration, as well as, help in management measures that minimize the effect of the thermal challenge and enable the maximization of productivity animal (Menêses, 2016). This research aimed to carry out the environmental diagnosis for dairy cattle in the municipality of João Pessoa, Brazil, based on average, maximum and minimum temperatures, BGHI and relative humidity.

\section{Materials and Methods}

This research was developed in the Laboratory of Rural Constructions and Ambience (LaCRA), at the Universidade Federal de Campina Grande. Data from the historical series of the municipality of João Pessoa was located in the state of
Paraíba, Brazilian Northeast, with geographical coordinates $07^{\circ} 06^{\prime} 54^{\prime \prime} \mathrm{S}$ and $34^{\circ} 51^{\prime} 47^{\prime \prime} \mathrm{W}$ and $47 \mathrm{~m}$ above sea level. The environmental variables analyzed were: relative humidity (RH, \%), maximum temperature (Tmax, $\left.{ }^{\circ} \mathrm{C}\right)$, mean temperature $\left(\mathrm{Tm},{ }^{\circ} \mathrm{C}\right)$ and minimum temperature $\left(\mathrm{Tmin},{ }^{\circ} \mathrm{C}\right)$ in 2013 and 2014. This data was used to calculate BGHI (Black Globe Temperature and Humidity Index).

For the bioclimatic diagnosis, Mahoney's methodology was used, in which three stages are explained: 1 . Refers to local climatic data (data system, maximum, minimum, BGHI, ventilation, and amplitude); 2. Compare with the animal requirements and determine the environmental acceptability limits; 3 . Identify the critical points and the constructive and energetic solutions to carry out their corrections (Fernandes 2011).

In the second stage, information was obtained on the needs of the animals at different life stages in which the critical temperature and BGHI were analyzed. With the analysis of the Tables 1 and 2, a spreadsheet with the bioclimatic diagnosis for cattle breeding in the municipality of João Pessoa was obtained, as well as the annual analysis of the region's climate.

Table 1 Climatic data in the municipality of João Pessoa.

\begin{tabular}{|c|c|c|c|c|c|c|c|c|c|c|c|c|c|c|c|c|}
\hline \multirow[b]{3}{*}{ Month $^{1}$} & 2013 & 2014 & Mean & & & & 2013 & 2014 & Mean & & & 2013 & 2014 & Mean & & \\
\hline & \multicolumn{6}{|c|}{ Mean temperature } & \multicolumn{5}{|c|}{ Maximum temperature } & \multicolumn{5}{|c|}{ Minimum temperature } \\
\hline & $\mathrm{Tm}$ & $\mathrm{Tm}$ & Mean & $\mathrm{RH}$ & TPO & BGHI & Tmax & Tmax & Mean & TPO & BGHI & Tmin & Tmin & Mean & TPO & BGHI \\
\hline 1 & 26.5 & 26.4 & 26.53 & 72.8 & 21.1 & 77.5 & 31.2 & 31.0 & 31.14 & 24.1 & 83.2 & 22.1 & 22.0 & 22.10 & 17.0 & 71.6 \\
\hline 2 & 26.6 & 26.4 & 26.54 & 64.3 & 18.4 & 76.5 & 31.3 & 31.1 & 31.26 & 22.9 & 82.9 & 22.1 & 22.0 & 22.10 & 15.6 & 71.1 \\
\hline 3 & 26.5 & 26.4 & 26.49 & 79.1 & 22.2 & 77.9 & 30.9 & 30.8 & 30.88 & 26.6 & 83.8 & 22.3 & 22.2 & 22.30 & 23.4 & 74.1 \\
\hline 4 & 26.0 & 26.0 & 26.07 & 77.4 & 21.9 & 77.3 & 30.5 & 30.5 & 30.56 & 26.3 & 83.4 & 22.1 & 22.2 & 22.20 & 23.3 & 74.0 \\
\hline 5 & 25.1 & 25.6 & 25.40 & 84.5 & 22.3 & 76.8 & 29.7 & 30.1 & 29.97 & 26.9 & 83.0 & 21.5 & 21.9 & 21.78 & 18.9 & 72.0 \\
\hline 6 & 24.1 & 24.6 & 24.44 & 81.9 & 20.5 & 75.2 & 28.9 & 29.4 & 29.15 & 25.1 & 81.6 & 27.4 & 21.2 & 24.32 & 25.5 & 76.9 \\
\hline 7 & 23.4 & 23.8 & 23.66 & 87.5 & 21.9 & 74.9 & 28.2 & 28.5 & 28.41 & 26.5 & 81.3 & 20.2 & 20.5 & 20.38 & 18.6 & 70.4 \\
\hline 8 & 23.7 & 24.0 & 23.92 & 74.8 & 19.0 & 74.1 & 28.5 & 28.8 & 28.68 & 23.6 & 80.5 & 19.6 & 19.9 & 19.83 & 14.0 & 68.3 \\
\hline 9 & 24.5 & 24.7 & 24.66 & 64.7 & 18.3 & 74.6 & 29.5 & 29.7 & 29.68 & 23.0 & 81.3 & 20.2 & 20.4 & 20.36 & 12.1 & 68.1 \\
\hline 10 & 25.4 & 25.7 & 25.59 & 69.9 & 19.0 & 75.8 & 30.2 & 30.5 & 30.39 & 25.0 & 82.8 & 20.7 & 21.0 & 20.93 & 14.8 & 69.6 \\
\hline 11 & 26.0 & 26.2 & 26.16 & 70.0 & 19.4 & 76.5 & 31.1 & 31.3 & 31.22 & 26.9 & 84.3 & 21.0 & 21.2 & 21.15 & 17.4 & 70.8 \\
\hline 12 & 26.4 & 26.6 & 26.57 & 73.2 & 21.1 & 77.5 & 31.1 & 31.3 & 31.22 & 26.9 & 84.3 & 21.4 & 21.7 & 21.60 & 17.8 & 71.4 \\
\hline
\end{tabular}

\section{Results and Discussion}

According to Baêta and Souza (2010), the environment comprises all the physical, chemical, biological, social and climatic factors that interact with the animal, causing reactions in the behavior of these animals, thus defining the environment-animal relationship type. In this way, the animal behaves like a thermodynamic system, which continuously exchanges energy with the environment. In this process, the meteorological variables tend to produce internal temperature variations in the animal, influencing the energy amount exchanged between both, but there is, however, the need for physiological adjustments for the occurrence of thermal equilibrium.

For the bioclimatic analysis, the following symbologies were adopted: L - lower than required by cattle, $\mathrm{S}$ - higher than required by cattle, and C - comfortable for cattle. 
Table 2 Ideal values of superior critical temperature $\left(\mathrm{SCT},{ }^{\circ} \mathrm{C}\right)$ and lower critical temperatures $\left(\mathrm{LCT},{ }^{\circ} \mathrm{C}\right)$ for dairy cattle.

\begin{tabular}{lccc}
\hline Category & SCT & LCT & BGHI \\
\hline Dairy cattle & 5.0 & 25.0 & $>74$ \\
Dairy heifers & 10.0 & 32.0 & $>74$ \\
Calves & 7.0 & 27.0 & $>74$ \\
\hline
\end{tabular}

Source: Youlsef (1985), Roenfeldt (1998) and Baêta (1985)

According to Table 3, we observed that from January to April the average temperature was higher than that demanded dairy cows. From June to September, the temperature was within the thermal comfort zone. In the months of October to December, the temperature was higher than the superior critical range thus reaching its production capacity. For the maximum temperature, all the months were superior, since the minimum temperature for every month did not exceed the thermal comfort zone for these animals. Our analysis suggests that the animal production capacity was negatively affected due to the heat stress caused by temperatures above the upper critical limit, being a point of great relevance because the nutrients provided by the animals' diet will be used for maintenance purposes instead of milk production (Baêta e Souza 2010).

Heat stress is a typical problem found in the dairy cows management in the tropics and subtopics, causing reductions in production and changes in milk composition, besides feed intake reduction and an increase in water intake. The drop in milk production due to the increase in environmental temperature depends on factors such as relative humidity, wind speed, nutrition and other factors related to handling. However, productive losses of $10 \%$ or more have been often observed (Head 1995).

Also according to Table 3, all temperature averages were within the thermal comfort zone required by dairy heifers, providing welfare and thus contributing to higher productivity. Currently, the rations are formulated for heifers taking into account environmental conditions (temperature, installation type, and wind incidence), which have a direct influence on animal energy requirements (Hoffman 1997). Hoffman et al (1995) described the environmental conditions effects on nutrient requirements, especially energy, for growing heifers.

Table 3 Bioclimatic diagnosis for dairy cattle breeding in the municipality of João Pessoa.

\begin{tabular}{cccccccccccccc}
\hline Stage/Months $^{1}$ & 1 & 2 & 3 & 4 & 5 & 6 & 7 & 8 & 9 & 10 & 11 & 12 \\
\hline BLG & SsCs & SsCs & SsCs & SsCs & SsCs & CsCs & CsCs & CsCs & CsCs & SsCs & SsCs & SsCs \\
NL & CcCs & CcCs & CcCs & CcCs & CcCs & CcCs & CcCs & CcCs & CcCs & CcCs & CcCs & CcCs \\
B & CsCs & CsCs & CsCs & CsCs & CsCs & CsCs & CsCs & CsCs & CsCs & CsCs & CsCs & CsCs
\end{tabular}

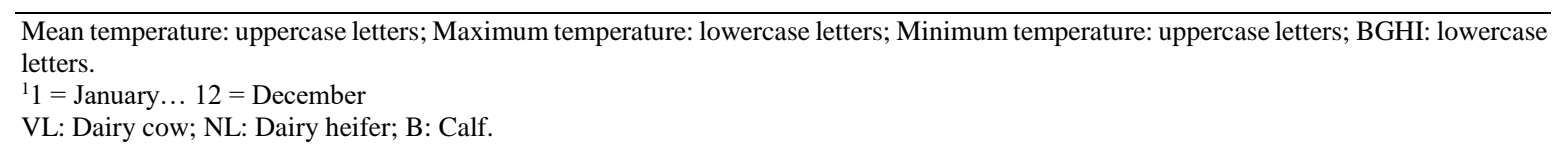

For calves, mean and minimum temperatures presented as thermally comfortable, while the maximum temperature was higher than TCZ, surpassing the critical temperature value. Calves are harmed by heat stress. The animal, when young, show an accelerated metabolism, besides its heart and respiratory rates were higher when it compared to an adult animal. The calf's thermoregulation is less efficient and, for this reason, the animal becomes more vulnerable to the ambient temperature oscillations and, in extreme situations, presents hyperthermia (Embrapa 2017).

For all phases, the BGHI was calculated using the maximum temperature, with values higher than 80.58 . For the BGHI calculated with the average temperature, the values were higher than 74.17. According to the National Weather Service (1976 apud Baêta 1985), BGHI values for lactating Holstein cows less than 74 represent thermal comfort conditions; 74 to 79 , alert; between 79 and 84, danger and above 84 indicate an emergency situation.
Baêta and Souza (2010) stated that animals exposed to solar radiation suffer more from heat stress than animals in shaded locations. This shading can be carried out in a natural way with the trees or artificial. The natural shading one more beneficial to the animal, because, the vegetation transforms the solar energy through the photosynthesis, reducing the solar radiation incidence during the day.

In order to reduce the temperature and cool the environment by preventing heat stress, several strategies can be used, such as ventilation systems, where, in this case, ventilation is recommended can be tunnel or longitudinal type (Baêta 2010). According to Lopes Neto (2017), it is possible to associate water sprinklers with ventilation, where this can occur either indirectly by sprinkling in the environment for air cooling, or directly on the animal's body surface on hot and dry days with the intention of reducing body temperature. Still according to the author mentioned above, the fan number 
should be enough to promote an air renewal every one or two minutes.

Another way to environment cooling is by cool the building elements (Baêta 1997), as the roofing material, using tiles types with a low-temperature transmission, such as ceramic tiles. To further improve the material efficiency on hot days, it is recommended to sprinkle water on the tiles in order to lower their temperature.

Finally, there are some ways to avoid the direct action of solar radiation and may use light-colored paint to radiation reflect (Lopes Neto 2017). It is also recommended to plant grass on the ground around the facilities, reducing the incident radiation inside the facility, thus achieving an ambient temperature reduction (Lopes Neto 2017).

\section{Conclusions}

According to our analysis, the bioclimatic diagnosis for João Pessoa, both dairy cows and calves have thermal discomfort caused by high temperatures. As a way to reduce heat stress, it is necessary for the improvement of the facilities that to provide the thermal comfort to the animals, thus making it possible for these animals to present a higher production yield. In this way, structural modifications must be carried out at the facilities, so that the temperature is within or near the thermal comfort zone for each life stage of the dairy cattle.

\section{References}

Baêta FC, Souza FC (2010) Ambiência em edificações rurais: conforto animal. Universidade Federal de Viçosa, Viçosa.

Carvalho PCF, Moraes SA (2005) Comportamento ingestivo de ruminantes: bases para o manejo sustentável do pasto.In: Manejo Sustentável em Pastagem, 1, Maringá. Anais... Maringá: UEM.

Domingos HGT, Maia ASC, Souza Jr JBF, Silva RB, Vieira FMC, Silva RG (2013) Effect of shade and water sprinkling on physiological responses and milk yields of Holstein cows in a semiarid region. Livestock Science 154:169-174.

FAO - Food and Agriculture Organization of the United Nations. FAOSTAT (2014). Disponível em: Acesso em: 27 janeiro 2015.

Fernandes JT (2011) Código de obras e edificações do DF: inserção de conceitos bioclimáticos, conforto térmico e eficiência energética. 249p. Dissertação de Mestrado em Arquitetura e Urbanismo. Faculdade de Arquitetura e Urbanismo, Universidade de Brasília UnB, Brasília.

Head HH (1989) The strategic use of the physiological potential of the dairy cow. In: SIMPÓSIO LEITE NOS TRÓPICOS: novas estratégias de produção, Botucatu. Anais... Botucatu: UNESP, 1989. p. 38-89.

Hoffman PC (1997) A new look at our old heifer-rasing rules. Hoard's Dairyman 142:814-827.

Hoffman, P.C., Brehn, N.M., Howard, W.T. et al. (1995) The influence of nutrition and environment on growth of Holstein replacement heifer in commercial dairy herds. Animal Science 10:49.
Lopes Neto JP (2017) Construções e instalações rurais. NT editora: Brasília, 138p.

IBGE - Instituto Brasileiro de Geografia e Estatística. Censo Agropecuário 2006.

Medeiros, L.F.D.; Vieira, D.H. Bioclimatologia animal. (1997). Disponível em: http://www.iz.ufrj.br/zootecnia_draa/biblioteca/Fernando/apostila\% 20I.pdf. Acesso em: 12 de novembro 2013.

Pereira CCJ (2005). Fundamentos de bioclimatologia aplicados à produção animal. Belo Horizonte: FEPMVZ, 195p.

Rashamol VP, Sejian V, Bagath M, Krishnan G, Archana PR, Bhatta R (2018) Physiological adaptability of livestock to heat stress: an updated review. Journal of Animal Behaviour and Biometeorology, 6:62-71.

Zanine AM, Vieira BR, Ferreira DJ (2007) Comportamento ingestivo de bovinos de diferentes categorias em pastagem de capim Coastcross. Bioscience Journal 23:111- 119. 